\title{
Relationships Between Nurses' Perceptions of Patient Safety Culture and Job Stress, Trust, Identification, and Leadership*
}

\section{Hemşirelerin Hasta Güvenliği Kültürü Algısı ile İş Stresi, Güven, Özdeşleşme, Liderlik Arasındaki İlişkiler}

\section{Abstract}

Introduction: Offering a high-quality and cost-effective healthcare system that prioritises patient safety requires establishing a common patient safety culture. In this regard, stakeholders need to determine the factors that affect the perception of the patient safety culture to support a healthy and safe working environment.

Aim: The study aims to analyze the relationship between the perception of patient safety culture and job stress, organizational trust, organizational identification, and leadership. It also aims to determine the determinants of patient safety perceptions.

Method: This cross-sectional study was conducted between May 1 and October 1, 2017, with nurses working in a public hospital in a city in Turkey. The research group consists of 150 nurses. Regression, correlation, T-test, and Kruskal Wallis analyzes were performed in the study.

Results: A positive and significant relationship was found between the perception of patient safety culture and leadership, organizational identification, and organizational trust. There was a negative but significant relationship between patient safety culture perceptions and job stress. The multiple regression analysis results showed that leadership, organizational identification, and job stress were determinants of patient safety culture perceptions.

Conclusion: Hospitals should adopt management approaches that reduce the job stress of their personnel to establish and improve the patient safety culture. Furthermore, hospital management and leadership aiming to improve organizational trust and identification levels across personnel would positively contribute to the patient safety culture.

Keywords: Nursing, patient safety, leadership, organizational identification, job stress, organizational trust.
Recieved / Geliş: 20.05.2021

Accepted / Kabul: 25.08.2021

Published Online / Online Yayın: 25.12.2021

Corresponding author / Sorumlu yazar:

Sabahattin Tekingündüz Mersin University, School of Health, Department of Health Care Management, Mersin, Turkey. stekingunduz@mersin.edu.tr ORCID: 0000-0002-2528-9029

E. Yıldız 0000-0002-9327-0653 Mersin University, Faculty of Nursing,

Department of Fundamentals of Nursing, Mersin, Turkey.

R. İnci 0000-0002-6855-4574 Batman University, Sağlık Yüksekokulu, Department of Nursing, Batman, Turkey.

*This study was carried out by Mersin University. Scientific Research Projects Coordination Unit (BAP) (20172-AP2-2545). Also, on 25-28 April 2018 organized in Antalya "12. International

in Health Services Accreditation Quality and Patient Safety Congress" presented as an oral presentation. 


\section{Öz}

Giriș: Hasta güvenliğine öncelik veren yüksek kaliteli ve uygun maliyetli bir sağlık sistemi sunmak, ortak bir hasta güvenliği kültürü oluşturmayı gerektirir. Bu bağlamda, paydaşların sağlıklı ve güvenli bir çalışma ortamını desteklemek için hasta güvenliği kültür algısını etkileyen etmenlerin belirlenmesi gerekir.

Amaç: Çalışmanın amacı, hasta güvenliği kültürü algısı ile iş stresi, örgütsel güven, örgütsel özdeşleşme ve liderlik arasındaki ilişkiyi incelemek ve hasta güvenliği kültür algısının belirleyicilerini saptamaktır.

Yöntem: Kesitsel tipteki bu çalışma, 1 Mayıs - 1 Ekim 2017 tarihleri arasında Türkiye'deki bir şehirde bir devlet hastanesinde çalışan hemşirelerle gerçekleştirildi. Araştırma örneklemi 150 hemşireden oluşmaktadır. Çalışmada regresyon, korelasyon, T testi ve Kruskal Wallis analizleri yapıldı.

Bulgular: Hasta güvenliği kültürü algısı ile liderlik, örgütsel özdeşleşme ve örgütsel güven arasında pozitif yönde anlamlı ilişki bulundu ve hasta güvenliği kültürü algısı ile iş stresi arasında negatif ancak anlamlı bir ilişki vardı. Çoklu regresyon analizi sonuçları, liderlik, örgütsel özdeşleşme ve iş stresinin hasta güvenliği kültürü algısının belirleyicileri olduğunu gösterdi.

Sonuç: Hastaneler, hasta güvenliği kültürünü oluşturmak ve geliştirmek için personelinin iş stresini azaltan yönetim yaklaşımlarını benimsemelidir. Ayrıca, personel genelinde örgütsel güveni ve örgütsel özdeşleşme düzeylerini geliştirmeyi amaçlayan hastane yönetimi ve liderliği, hasta güvenliği kültürüne olumlu katkılar sağlayacaktır.

Anahtar Sözcükler: Hemşirelik, hasta güvenliği, liderlik, örgütsel özdeşleşme, iş stresi, örgütsel güven.

\section{Introduction}

Health systems are complex organizations that involve inherently unpredictable risks affecting the safe delivery of patient care. Patient safety is the most essential component of health care quality and it is a priority for every health care system in ensuring and developing the quality of health care. The increasing global interest in improving the quality of healthcare services and improving patient safety has paved the path for developing relevant policies in this field (Kim, Yoo and Seo, 2018; Mauti and Githae, 2019; Vaismoradi, Griffiths, Turunen and Jordan, 2016).

Patient safety has been explained as "the reduction of risk of unnecessary harm associated with healthcare to an acceptable minimum" (Lee et al., 2019). Adverse events can be explained as abominable and unexpected incidents in care that may bring about adverse outcomes or may ask for supplementary care attempt to prevent an adverse outcome. In hospitalized patients, adverse events have a crucial clinical and fiscal affect, resulting in higher morbidity and mortality, longer hospital stays, incremental costs, diminish trust in health care systems, and adversely affect patient/patients' relatives and health care providers (Filiz, 2009; Sousa-Pinto, Marques, Lopes and Freitas, 2018).

Offering a high-quality and cost-effective healthcare system that prioritizes patient safety requires establishing a common patient safety culture. In this regard, stakeholders need to define the factors that affect the patient safety culture to support a healthy and safe working environment (Kim et al., 2018; Vaismoradi et al., 2016). The literature shows favorable changes in outcomes of care at patient safety-centered hospitals (Dicuccio, 2015), with less surgical site infections (Fan, Zheng, Liu and Li, 2016) and reduced medical errors (Vaismoradi et al., 2016), shorter length of stay, and lower rates of falls and in-hospital mortality (Leone and Adams, 2016). However, despite the improvement in patient safety, preventable errors still occur, and the resulting negative outcomes continue to pose an important problem in nursing and healthcare (Mauti and Githae, 2019; Rodziewicz, Houseman and Hipskind, 2021).

Job stress is described as the adverse physical and emotional reactions an individual develops against work-related factors that affect the individual's psychological and/or physical behavior when the requirements of the job fail to meet the employee's needs or resources and skills (Işıkhan, 2017). In healthcare services, where job stress tends to be the most intense, nurses have been informed to experience moderate or high levels of stress (Simonetti and Bianchi, 2016). These factors include poor communication, inadequate training, dealing with potentially suicidal patients, the threat of unforeseen conditions, unpredictable patient behavior, complex technological equipment, critical patient care, intense working hours, workload, violence, low motivation, conflict with team members (Hasan, Elsayed and Tumah, 2018; Mert, Sayilan and Baydemir, 2021). Nurses who work at institutions with a positive patient safety culture have been reported to achieve job satisfaction and psychological wellbeing (Brunetto et al., 2016), without experiencing exhaustion, and show better skills of coping with stressful circumstances (Vifladt, Simonsen, Lydersen and Farup, 2016). Stress causes reduce organizational and employee performance, high error rates, staff turnover, and absenteeism and negative health outcomes such as anxiety, emotional disorder (Akkoç, Okun and Türe, 2020). 


\section{Nurses' perceptions of patient safety culture}

Hemşirelerin hasta güvenliği kültürü algısı

Trust, main component of health care, reinforces the relationship in which clinicians and patients can work together for better care. Organizational trust is regarded as an informal agreement between staff, the organization, or the managers of the organization. Organizational trust, defined by the desire to express goodwill and trust in others' words and actions, is a dimension that contains both horizontal and vertical factors (Chen et al., 2015; Firth-Cozens, 2004). In today's world, where quality studies and patient safety practices are carried out in parallel, the importance of organizational trust becomes more prominent. Trust is main component of health care in terms of not only the relationship between clinicians and patients but also the relationship between staff and administration. Studies suggest that organizational trust affects many areas of working life such as job satisfaction, organizational commitment, and organizational effectiveness, and these factors affect the quality of patient care (Firth- Cozens, 2004; Top, Tarcan, Tekingündüz and Hikmet, 2013).

Organizational identification reflects the psychological situation between an employee and the organization and refers to the individual's feeling of being a part of the organization (Eker, 2015). An employee who recognizes themselves as a part of the organization tends to voluntarily accept the decisions made and actions taken by the organization (Kpakol, Obiora and Jaja, 2016). Through identification, the individual not only acknowledges who he or she is, but also gains the capacity to perceive himself or herself differently, to perceive similarities, and to understand collective life. Identification occurs upon the creation of a sense of belonging when individuals' beliefs about the organization become a reference for their perception (Vieira, Alves, Monteiro and Garcia, 2013). While employees identify with their organizations to meet their need for a sense of belonging and diminish uncertainty, institutions aim to strengthen organizational identification since they believe that identity will have a positive impact on employee performance (Bacaksiz, Tuna and Seren, 2017).

The principal aim of nursing is to ensure and maintain patient care and providing the best nursing services in healthcare institutions that offer inpatient services with functions of treatment, care, training, and research requires that nurses adopt the institution, feel like a part of the organization and exhibit stronger organizational identification in parallel with this sense of belonging, and studies conducted with healthcare professionals have reported a positive and significant correlation between organizational identification and work performance (Şantaş, Uğurluoğlu, Kandemir and Çelik, 2017).

Transformational leadership has been explained as a leadership style intended to "motivate and inspire followers to pursue higher-order goals through the transformation of followers' attitudes, beliefs, values, and behaviors". Transformational leadership is a form of leadership that pushed audiences to a higher level of performance. Meanwhile, the subordinates of transformational leaders also have a high motivation to accomplish incredible performance. It has become a predominant leadership style practiced by leaders across many industries and disciplines, including nursing (To, Tse, and Ashkanasy, 2015; Giddens, 2018; Herminingsih, 2020). Having an important position in the health sector, nursing is a dynamic and challenging profession that requires engaging and inspiring role models and leadership in today's ever-changing and demanding health environment. In the context of nursing services, leadership plays an important role in patient-stafforganization harmony. Although leadership styles are different, the leadership style developed may affect patient safety and evidence-based practices, quality care standards, open communication with staff, mortality, patient satisfaction, job performance, intention to stay, hospital infections, and hospitalization duration (Scully, 2015; Sfantou et al., 2017).

The present research aims to analyze the relationship between perception of patient safety culture and job stress, organizational trust, organizational identification, and leadership. Identifying the determinants of perception of patient safety culture is a secondary objective of this study. There are only a limited number of studies analyzing patient safety with organizational trust, organizational identification, and leadership, both at the international level and in Turkey.

\section{Method}

Purpose and Type of Research: The aim of this cross-sectional study is to analyze the relationship between perception of patient safety culture and job stress, organizational trust, organizational identification and leadership and determine the determinants of patient safety perception.

Research Question: Are there any causal interactions between the perception of patient safety culture and the concepts of job stress, organizational trust, organizational identification and leadership?

Population and Sample: This is a cross-sectional study based on the survey. The population of the research comprised 340 nurses who were working at a public hospital in a city in Turkey between May 1 and October 1, 2017. In line with the literature on this subject matter (Williams, 2014); with 0.05 Type I error and 80 percent power, the minimum number of 
subjects required for the study was 17 for the relationship between Perception of Patient Safety Culture and Job Stress at 0.626, 10 for the relationship between Perception of Patient Safety Culture and Organizational Trust at $0.797,18$ for the relationship between Perception of Patient Safety Culture and Organizational Identification at 0.655 , and 33 for the relationship between Perception of Patient Safety Culture and Leadership at 0.466 . Considering these calculations, the number of subjects to be included was a minimum of 33 individuals. A total of 150 nurses were registered by randomizations in this study. Thus, 44 percent of the population was reached.

Instrumentation: Personal information form: The form contains six questions (gender, service, age etc.) to determine the personal-job characteristics of the participants.

The Safety Culture Survey: The study used the Hospital Survey on Patient Safety Culture (HSOPSC) developed in 2004 by the Agency for Healthcare Research and Quality used to determine the patient safety culture of nurses in hospitals in the United States (Filiz, 2009). The HSOPSC assesses the culture of patient safety in the hospital as a whole or evaluates the units/services within a hospital. The instrument contains 42 expressions rated on a five-point Likert scale grouped into 12 dimensions of patient safety culture. The last part includes a question asking respondents to indicate the number of adverse events reported in the last 12 months. The instrument contains 18 reverse worded items. Filiz (2009) adopted the instrument for use in Turkish and found the Cronbach's alpha value as .86. This study was conducted based on the total score of the HSOPSC. High scores reflect a positive situation.

Job Stress Scale (JSS): The JSS was used to measure the concept of job stress or job tension. The JSS includes of seven items rated on a 5-point Likert scale. The scale ranges from strongly disagree (1) to strongly agree (5). Higher scores on the scale indicate higher levels of stress, while the lower score indicates lower levels of stress (Efeoğlu, 2006). Cronbach's alpha for JSS was .84.

Organizational Trust Scale: Developed by Tyler and Bies (2001), the organizational trust scale consists of four items. The response categories of the items in this scale are graded on a 5-point scale (1:Strongly Disagree, 5:Strongly Agree). The reliability and validity of the scale for use in Turkish were tested by Polat (2009). Cronbach's alpha for organizational trust was .88. High scores reflect a positive state of organizational trust.

Organizational Identification Scale: Developed by Mael and Ashforth (1992), the organizational identification scale consists of six items that are rated on a 5-point Likert scale (1:Strongly Disagree, 5:Strongly Agree). The scale was adapted by Tüzün (2006) for use in Turkish. Cronbach's alpha for organizational identification was .78. High scores reflect a positive state of organizational identification

Leadership Scale: There are various transformational leadership scales in the literature. However, most of them are long and time-consuming. For this reason, the 7-item Global Transformational Leadership Scale developed by Carless, Wearing and Mann (2000) was used in this study. The validity and reliability of the scale have been proven and can be completed in a short time. The scale uses a five-point Likert scale with a range of responses of "rarely or never" to "frequently, if not always". The scale assesses the following components of transformational leadership behaviors: communicating a vision, developing staff, providing support, empowering staff, being innovative, leading by example, and being charismatic. Cronbach's alpha for transformational leadership was. 93 (Carless et al., 2000). High scores reflect a positive state of leadership.

Statistical Analysis: Descriptive statistics were used to calculate the means and standard deviations of perception of patient safety culture, job stress, organizational trust, organizational identification, and leadership scores. The relationship between the perception of patient safety culture and job stress, organizational trust, organizational identification, and leadership was examined using correlation analysis. Multiple linear regression analysis was used to determine the factors that affect the perception of patient safety culture. The difference between the perception of patient safety culture and personal-job characteristics (e.g. age, service) was evaluated using t-test and Kruskal Wallis tests. The correlation between perception of patient safety culture and other variables (e.g. age, duration of professional experience, weekly working time) was also evaluated using correlation analysis.

Ethical Approval: The research was endorsed by one university, Social Sciences and Humanities Ethics Committee with the number 22125045/771-2017. Attenders were informed about the research, and the informed consent form was obtained.

Study Limitations: The results of the present study cannot be generalized since the study has been conducted at a single state hospital in a single city in Turkey. Nurses in the study, nurses were randomly selected. 


\section{Results}

The findings regarding the personal-job characteristics of the participants are shown in Table 1.

Table 1. Personal-job characteristics of the participants $(\mathrm{N}=150)$

\begin{tabular}{lcc} 
& Number & Percentage \\
\hline Gender & & 58.0 \\
Female & 87 & 42.0 \\
Male & 63 & 12 \\
Service & & 60.7 \\
Outpatient unit & 18 & 27.3 \\
Inpatient unit & 91 & 41 \\
Critical care unit & & \\
& & $\mathbf{X} \pm$ SD \\
Age & & $32.45 \pm 6.53$ \\
Duration of professional experience (years) & $9.16 \pm 5.722$ \\
Weekly working time (hours) & $45.55 \pm 8.011$ \\
\hline
\end{tabular}

Note. ${ }^{a}$ Emergency, intensive care, operating room. $\overline{\mathrm{X}}$ : Mean, SD: Standard deviation

Among the nurses participating in the study, $58 \%$ were women and $60.7 \%$ were working in inpatient services. The mean age of the participants was $32.45 \pm 6.5$ years, their mean duration of professional experience was $9.16 \pm 5.7$ years, and their mean weekly working time was $45.55 \pm 8.0$ hours (Table 1 ).

Table 2. Number of adverse events reported*

\begin{tabular}{|c|c|c|}
\hline & Number & Percentage \\
\hline None & 79 & 52.7 \\
\hline 1 - 2 adverse events & 47 & 31.3 \\
\hline 3 - 5 adverse events & 15 & 10.0 \\
\hline 6 adverse events or more & 9 & 6.0 \\
\hline Total & 150 & 100.0 \\
\hline
\end{tabular}

Note. ${ }^{*}$ Number of adverse events reported in the last 12 months.

It was found that $52.7 \%$ of the nurses did not report any adverse events in the last 12 months, $31.3 \%$ reported $1-2$ adverse events, and 10\% reported 3-5 adverse events (Table 2).

Table 3. Mean, standard deviation, reliability and correlation matrix for variables

\begin{tabular}{|c|c|c|c|c|c|c|}
\hline & $\overline{\mathbf{X}} \pm S D$ & $\alpha^{\star \star \star}$ & 1 & 2 & 3 & 4 \\
\hline Perception of Patient Safety Culture (1) & $3.01 \pm 0.53$ & 0.86 & 1 & & & \\
\hline Job Stress (2) & $3.46 \pm 0.95$ & 0.87 & $-.358^{* *}$ & 1 & & \\
\hline Organizational Trust (3) & $2.77 \pm 0.97$ & 0.76 & $.223^{* *}$ & -.008 & 1 & \\
\hline Organizational Identification (4) & $3.55 \pm 1.03$ & 0.92 & $.327^{\star *}$ & .121 & -.046 & 1 \\
\hline Leadership (5) & $2.59 \pm 1.55$ & 0.96 & $.512^{\star \star}$ & $-.307^{\star *}$ & $.504^{\star \star}$ & $.184^{*}$ \\
\hline
\end{tabular}

Note. *. Correlation is significant at the 0.05 level (2-tailed).

**. Correlation is significant at the 0.01 level (2-tailed).

***. Cronbach's Alpha

$\overline{\mathrm{X}}$ : Mean, SD: Standard deviation

Table 3 shows the relationships between the perception of patient safety culture and job stress, organizational trust, organizational identification, and leadership. We found a positive and significant relationship between perception of patient safety culture and organizational trust, organizational identification, and leadership. However, there was a negative and significant relationship between perception of patient safety culture and job stress. The internal consistency coefficients of the scales were over .70 . 
Table 4. Regression model for the determinants of perception of patient safety culture

\begin{tabular}{|c|c|c|c|c|c|c|c|}
\hline & \multicolumn{2}{|c|}{$\begin{array}{l}\text { Unstandardized } \\
\text { Coefficients }\end{array}$} & \multirow{2}{*}{$\begin{array}{c}\begin{array}{c}\text { Standardized } \\
\text { Coefficients }\end{array} \\
\text { Beta }\end{array}$} & \multirow[t]{2}{*}{$t$} & \multirow[t]{2}{*}{$\mathbf{p}$} & \multirow[t]{2}{*}{ Tolerance } & \multirow[t]{2}{*}{ VIF } \\
\hline & B & SE & & & & & \\
\hline (Constant) & 2.515 & .206 & & 12.196 & .000 & & \\
\hline Job Stress & -.166 & .040 & -.293 & -4.114 & .000 & .832 & 1.202 \\
\hline Organizational Trust & .037 & .043 & .067 & .862 & .390 & .692 & 1.445 \\
\hline Organizational Identification & .160 & .036 & .305 & 4.441 & .000 & .892 & 1.121 \\
\hline Leadership & .155 & .039 & .332 & 3.950 & .000 & .594 & 1.684 \\
\hline
\end{tabular}

Note. $R=0.624 ; R 2=0.390 ; F=23.172 ; p=0.0001$; Durbin Watson=1.684, ${ }^{*} p<0.05$; significant predictor. $S E$, standard error, Dependent variable: perception of patient safety culture.

As shown in Table 4, a regression model was developed to define the effect of job stress, organizational trust, organizational identification, and leadership on the perception of patient safety culture. The model included the perception of patient safety culture as a dependent variable and job stress, organizational trust, organizational identification, leadership as independent variables. This regression model was found to be linear and statistically significant $(F=23.172 ; p=0.0001)$.

The independent variables of the model explain 39 percent of the total change in the variable of perception of patient safety culture. In the model, a positive contribution to the perception of patient safety culture was observed with organizational identification and leadership, while job stress was associated with a negative contribution. Furthermore, the leadership dimension provided the most significant contribution to the model (std. $\beta=0,332$ ).

Table 5. Difference/relationship between perception of patient safety culture and personal-job characteristics

\begin{tabular}{lc}
\multicolumn{1}{c}{ HSOPSC } \\
$\overline{\mathbf{X}} \pm$ SD \\
\hline Gender & $3.014 \pm 0.50$ \\
$\quad$ Female & $3.009 \pm 0.58$ \\
$\quad$ Male & 0.56 \\
$t \quad 0.96$ \\
$p$ & Mean Rank \\
Service & \\
$\quad$ Outpatient unit & 95.94 \\
Inpatient unit & 73.80 \\
$\quad$ Critical care unit & 70.29 \\
$x^{2}$ & 4.714 \\
$p$ & 0.96 \\
Age & \\
$r$ & -0.035 \\
$p$ & 0.67 \\
Duration of professional experience & \\
$r$ & -0.048 \\
$p$ & 0.56 \\
Weekly working time & \\
$r$ & -0.051 \\
$p$ & 0.53 \\
\hline
\end{tabular}

Note. HSOPSC: Hospital Survey on Patient Safety Culture, $\mathrm{p}<0.05$; significant predictor

Table 5 presents the results showing the difference/relationship between perception of patient safety culture and personaljob characteristics. According to the results of the univariate analysis, there was no difference between the perception of patient safety culture and gender and service $(p>0.05)$. Also, there was no correlation between perception of patient safety culture and age, duration of professional experience, and weekly working time $(p>0.05)$. 


\section{Discussion}

Health care systems are complex organizations involving inherently unforeseeable risks that affect the safe delivery of patient care (Mansour, 2015). To cope with these complexities, it is vital to create a positive patient safety culture (Sütçü, 2019). With the increasing significance of reducing adverse events in health services, the creation of patient safety culture has become a strategic necessity (Williams, 2014). Study has indicated that the economic costs of adverse events are also significant, and the burden in developed countries remains high (Braithwaite, Herkes, Ludlow, Testa, and Lamprell, 2017). O'Donovan, Ward, De Brún and McAuliffe (2019) found that safety culture improved safety outcomes including accident prevention and safety compliance as well as fewer adverse events. Accomplishing a culture of safety requires an grasp of the values, attitudes, beliefs, and norms that are important to health care organizations and what attitudes and behaviors are appropriate and expected for patient safety (Lawati, Dennis, Short, and Abdulhadi, 2018).

In this study, it was determined that $52.7 \%$ of nurses did not report any incidents in the last 12 months, $31.3 \%$ reported $1-2$ incidents and 10\% reported 3-5 incidents. Nurses and physicians fear reporting medical errors due to fear of punishment and lack of confidentiality. The scares among health persons involved; legal effects, fear of losing a job, fear of punishment, and fear of bullying (Mauti and Githae, 2019). In a study with nurses by Yıldız and Yıldız (2020), 79.9\% of the nurses reported that they did not report some medication errors during their nursing careers.

The correlation analysis in this study found positive and significant relationships between the perception of patient safety culture and organizational trust, organizational identification, and leadership. However, there was a negative correlation between the perception of patient safety culture and job stress. According to the regression analysis, $39 \%$ of the total change in the perception of patient safety culture could be explained by the independent variables in the model. According to the analysis results, leadership and organizational identification positively affected the perception of patient safety culture, whereas job stress affected it negatively.

In studies on patient safety, achieving positive outcomes at the institution level depend on the primary adoption of the subject among leaders. Boamah, Spence Laschinger, Wong and Clarke (2018) found that transformational nurse managers developed patient care quality by designing work environments that enable nurses to feel empowered to provide optimal care. In nursing, leadership is one of the factors that affect the reliability and quality of care at the hospital (Livne, Rashkovits, Peterfreund and Sheps, 2017).

Koç, Eraydın and Tezcan (2020) reported a high mean score of management and perception of leadership; however, the authors recommended improving these scores and supporting intermediate managers, emphasizing that the necessary organizational change relies on managers. In a study with nurses, as reported by Williams (2014), positive and strong relationships were observed between patient safety culture and the three variables (i.e. organizational commitment, job satisfaction, transformational leadership). According to the results of the multiple regression analysis, these three variables accounted for $66.6 \%$ of the change in perception of patient safety culture. In different studies, leadership was found to be one of the main external factors in developing the belief and intention of patient safety culture. Kim et al. (2018) reported a higher perception of patient safety culture with positive leadership and a supportive management approach, and in line with these results, Vaismoradi et al. (2016) also reported favorable effects on patient outcomes in the presence of participative and supportive management. Farokhzadian, Nayeri and Borhani (2018) emphasized the lower work motivation and productivity observed with inadequate and non-participative management in addition to inadequate leadership, while Reis, Paiva and Sousa (2018) highlighted the unfavorable effects of no supportive management and leadership on the institutionalization of safety culture. Brewer et al. (2016) revealed the effects on safety practices of employees resulting from leadership which exhibits a positive association with patient safety culture. Brasaite, Kaunonen, Martinkenas and Suominen (2016) determined that health professionals generally developed positive attitudes towards job satisfaction, teamwork, management perception, safety climate, and working conditions.

The trust of staff in their leader is a key element in the formation of a patient safety culture. To develop a patient safety culture, staff should be able to trust their leaders/managers, trust that errors will be handled justly and sentiently, and believe that the person reporting the error will be treated fairly and will not have any negative results (Livne et al., 2017). The correlation analysis in our study found a positive correlation between the perception of patient safety culture and organizational trust. However, according to the regression analysis, organizational trust had no significant effect on the perception of patient safety culture. We could suggest that an employee who identifies with his or her organization and sees himself or herself as a part of the organization voluntarily supports patient safety practices. High identification and positive leadership perception may make patient safety practices more effective in a healthcare organization. Hospital 
management must determine the factors that create stress among the staff. Elimination of these stress factors by the management or minimizing their effects could affect patient safety positively.

In this study, it was determined that there was no difference (in terms of gender and service) or relationship (in terms of age, duration of professional experience, and weekly working time) between the perception of patient safety culture and personal-job variables. However, there are studies in the literature suggesting that personal characteristics and factors in the work environment affect the perception of patient safety culture (Williams, 2014; Yıldız and Yıldız, 2020).

\section{Conclusion}

Hospitals should adopt management approaches that reduce the job stress of their nurses to establish and improve the patient safety culture. Future studies that include other healthcare professionals across university hospitals and private hospitals may yield more efficient results. This study provides a significant contribution to the relevant literature in that it shows the positive effect of organizational trust, organizational identification and leadership, and the negative effect of job stress on patient safety. In light of these findings, we believe the association between patient safety and employees' approach and behavior presents an important matter of debate both for policymakers and academicians as well as healthcare institutions. Furthermore, a working environment based on collaboration and trust, effective communication at every level, and information sharing may encourage adverse event reporting, lower job stress levels, and aid in establishing a patient safety culture. Longitudinal studies are warranted to understand the causal interactions between patient safety and job stress, organizational trust, organizational identification, and leadership.

Ethics Committee Approval: Ethical approval was obtained with the decision of the Mersin University, Social Sciences and Humanities Ethics Committee with the number 22125045/771-2017.

Conflict of Interest: Not reported.

Funding: None.

Informed Consent: Written consents of the participants were obtained.

\section{References}

Akkoç, I.., Okun, O. \& Türe, A. (2020). The effect of role-related stressors on nurses' burnout syndrome: The mediating role of work-related stress. Perspectives in Psychiatric Care, 57(2), 583-596. https://doi.org/10.1111/ppc.12581.

Bacaksiz, F. E., Tuna, R. \& Seren, A. K. H. (2017). The relationships between organizational identification, job performance, and job crafting: A study among nurses. International Journal of Caring Sciences, 10(1), 251-259.

Boamah, S. A., Spence Laschinger, H. K., Wong, C. \& Clarke, S. (2018). Effect of transformational leadership on job satisfaction and patient safety outcomes. Nursing Outlook, 66(2), 180-189. https://doi.org/10.1016/j.outlook.2017.10.004.

Braithwaite, J., Herkes, J., Ludlow, K., Testa, L. \& Lamprell, G. (2017). Association between organizational and workplace cultures, and patient outcomes: Systematic review. BMJ Open, 7, 1-11. https://doi.org/10.1136/bmjopen-2017-017708.

Brasaite, I., Kaunonen, M., Martinkenas, A. \& Suominen, T. (2016). Health care professionals' attitudes regarding patient safety: Crosssectional survey. BMC Research Notes, 9(1), 1-7. https://doi.org/10.1186/s13104-016-1977-7.

Brewer, C. S., Kovner, C. T., Djukic, M., Fatehi, F., Greene, W., Chacko, T. P. \& Yang, Y. (2016). Impact of transformational leadership on nurse work outcomes. Journal of Advanced Nursing, 72(11), 2879-2893. https://doi.org/10.1111/jan.13055.

Brunetto, Y., Xerri, M., Farr-Wharton, B., Shacklock, K., Farr-Wharton, R. \& Trinchero, E. (2016). Nurse safety outcomes: Old problem, new solution-the differentiating roles of nurses' psychological capital and managerial support. Journal of Advanced Nursing, 72(14), 27942805. https://doi.org/10.1111/jan.13036.

Carless, S. A., Wearing, A. J. \& Mann, L. A. (2000). Short measure of transformational leadership. Journal of Business and Psychology, 14(3), 389-406. https://doi.org/10.1023/A:1022991115523.

Chen, S. Y., Wu, W. C., Chang, C. S., Lin, C. T., Kung, J. Y., Weng, H. C. \& Lee, S. I. (2015). Organizational justice, trust, and identification and their effects on organizational commitment in hospital nursing staff. BMC Health Services Research, 15(1), 1-17. https://doi.org/10.1186/s12913-015-1016-8. 
Dicuccio, M. H. (2015). The relationship between patient safety culture and patient outcomes: A systematic review. Journal of Patient Safety, 11(3), 135-142. https://doi.org/10.1097/PTS.0000000000000058.

Efeoğlu, i. (2006). The effects of work family conflict on job stress, job satisfaction and organizational commitment: A study in the pharmaceutical industry (Doctoral dissertation) Çukurova University, Health Sciences Institute. Adana, Turkey.

Eker, D. (2015). Instructor's organizational identification scale (validity and reliability). Journal of Research in Education and Teaching, 4(4), 118-124.

Fan, Y., Zheng, Q., Liu, S. \& Li, Q. (2016). Construction of a new model of job engagement, psychological empowerment and perceived work environment among Chinese registered nurses at four large university hospitals: Implications for nurse managers seeking to enhance nursing retention and quality of care. Journal of Nursing Management, 24(5), 646-655. https://doi.org/10.1111/jonm.12369.

Farokhzadian, J., Nayeri, D. N. \& Borhani, F. (2018). The long way ahead to achieve an effective patient safety culture: Challenges perceived by nurses. BMC Health Services Research, 18(1), 1-13. https://doi.org/10.1186/s12913-018-3467-1.

Filiz, E. (2009). Determination of perception of patient safety culture in hospitals and of health staff and patient attitudes about patient safety (Master's thesis). Selcuk University, Institute of Health Sciences. Konya, Turkey.

Firth-Cozens, J. (2004). Organizational trust: The keystone to patient safety. Quality and Safety in Health Care, 13(1), 56-61. https://doi.org/10.1136/qshc.2003.007971.

Giddens, J. (2018). Transformational leadership: What every nursing dean should know. Journal of Professional Nursing, 34(2), 117-121. https://doi.org/10.1016/j.profnurs.2017.10.004.

Hasan, A. A., Elsayed, S. \& Tumah, H. (2018). Occupational stress, coping strategies, and psychological-related outcomes of nurses working in psychiatric hospitals. Perspectives in Psychiatric Care, 54(4), 514-522. https://doi.org/10.1111/ppc.12262.

Herminingsih, A. (2020). Transformational leadership positive influence toward employee engagement through job satisfaction and its effect on improving organizational commitment. Journal Manajemen Dan Pemasaran Jasa, 13(2), $281-296$. https://doi.org/10.25105/jmpj.v13i2.6290.

Işıkhan, V. (2017). Stress management, from burnout to happiness. First Ed. Ankara: Nika Publications.

Kim, K. J., Yoo, M. S. \& Seo, E. J. (2018). Exploring the influence of nursing work environment and patient safety culture on missed nursing care in Korea. Asian Nursing Research, 12(2), 121-126. https://doi.org/10.1016/j.anr.2018.04.003.

Koç, Z., Eraydın, C. \& Tezcan, B. (2020). Determining nurses' perception of patient safety culture and the factors affecting perceptions. Celal Bayar University Health Sciences Institute Journal, 7, 102-109.

Kpakol, A. G., Obiora, N. J. \& Jaja, S. A. (2016). Employee participation and organizational identification: Implications of the mediating effect of organizational culture. European Journal of Business and Management, 8(11), 32-44.

Lawati, M. H. A. L., Dennis S., Short, S. D. \& Abdulhadi, N. N. (2018). Patient safety and safety culture in primary health care: A systematic review. BMC Family Practice, 19(1), 1-12. https://doi.org/10.1186/s12875-018-0793-7.

Lee, S. E., Scott, L. D., Dahinten, V. S., Vincent, C., Lopez, K. D. \& Park, C. G. (2019). Safety culture, patient safety, and quality of care outcomes: A literature review. Western Journal of Nursing Research, 41(2), 279-304. https://doi.org/10.1177/0193945917747416.

Leone, R. M. \& Adams, R. J. (2016). Safety standards: Implementing fall prevention interventions and sustaining lower fall rates by promoting the culture of safety on an inpatient rehabilitation unit. Rehabilitation Nursing, 41(1), 26-32. https://doi.org/10.1002/rnj.250

Livne, Y., Rashkovits, S., Peterfreund, I. \& Sheps, J. (2017). Head nurse characteristics and patient safety: The mediating role of patient safety climate. IOSR Journal of Nursing and Health Science, 6, 43-53.

Mael, F. \& Ashforth, B. E. (1992). Alumni and their alma mater: A partial test of the reformulated model of organizational identification. Journal of Organizational Behavior, 13(2), 103-123. 
Mansour, M. (2015). Factor analysis of nursing students' perception of patient safety education. Nurse Education Today, 35(1), 32-37. https://doi.org/10.1016/j.nedt.2014.04.020.

Mauti, G. \& Githae, M. (2019). Medical error reporting among physicians and nurses in Uganda. African Health Sciences, 19(4), 31073117. https://doi.org/10.4314/ahs.v19i4.33.

Mert, S., Sayilan, A. A. \& Baydemir, C. (2021). Nurse Stress Scale (NSS): Reliability and validity of the Turkish version. Perspectives in Psychiatric Care, 57(2), 443-454. https://doi.org/10.1111/ppc.12606.

O'Donovan, R., Ward, M., De Brún, A. \& McAuliffe, E. (2019). Safety culture in health care teams: A narrative review of the literature. Journal of Nursing Management, 27(5), 871-883. https://doi.org/10.1111/jonm.12740.

Polat, M. (2009). A field study on antecedents and consequences of organizational identification (Doctoral dissertation). Uludağ University, Health Sciences Institute. Bursa.

Reis, C. T., Paiva, S. G. \& Sousa, P. (2018). The patient safety culture: A systematic review by characteristics of hospital survey on patient safety culture dimensions. International Journal for Quality in Health Care, 30(9), 660-677. https://doi.org/10.1093/intqhc/mzy080.

Rodziewicz, T. L., Houseman, B. \& Hipskind, J. E. (2021). Medical Error Reduction and Prevention. USA, StatPearls Publishing. https://www.ncbi.nlm.nih.gov/books/NBK499956/.

Sütçü, N. (2019). The analysis of the understanding of patient at safety culture and the factors that affect it (Master's thesis). Marmara University, Health Sciences Institute. Istanbul, Turkey.

Scully, N. J. (2015). Leadership in nursing: The importance of recognising inherent values and attributes to secure a positive future for the profession. Collegian, 22(4), 439-444. https://doi.org/10.1016/j.colegn.2014.09.004.

Sfantou, D., Laliotis, A., Patelarou, A., Sifaki- Pistolla, D., Matalliotakis, M. \& Patelarou, E. (2017). Importance of leadership style towards quality of care measures in healthcare settings: A systematic review. Healthcare, 5(4), 73. https://doi.org/10.3390/healthcare5040073.

Simonetti, S. \& Bianchi, R. (2016). Stress of the nurse that works in hospitalization unit. Revista de Enfermagem UFPE on Line, 10(12), 4539-4546. https://doi.org/10.5205/1981-8963-v10i12a11521p4539-4546-2016.

Sousa-Pinto, B., Marques, B., Lopes, F. \& Freitas, A. (2018). Frequency and impact of adverse events in inpatients: A nationwide analysis of episodes between 2000 and 2015. Journal of Medical Systems, 42(3), 1-9. https://doi.org/10.1007/s10916-018-0898-5.

Şantaş, F., Uğurluoğlu, Ö., Kandemir, A. \& Çelik, Y. (2017). The investigation of the relationship between the level of organizational cynicism, job performance and organizational identification among health employees. Gazi University Journal of Faculty of Economics and Administrative Sciences, 18(3), 867-886.

To, M., Tse, H. \& Ashkanasy, N. (2015). A multilevel model of transformational leadership, affect, and creative process behavior in work teams. The Leadership Quarterly, 26(4), 543-556. https://doi.org/10.1016/j.leaqua.2015.05.005.

Top, M., Tarcan, M., Tekingündüz, S. \& Hikmet, N. (2013). An analysis of relationships among transformational leadership, job satisfaction, organizational commitment and organizational trust in two Turkish hospitals. International Journal of Health Planning and Management, 28(3), e217-e241. https://doi.org/10.1002/hpm.2154.

Tüzün, İ. (2006). The relationship among organizational, trust, organizational identity and organizational identification, an amprical study (Doctoral dissertation). Gazi University, Health Sciences Institute. Ankara, Turkey.

Tyler, T. R. \& Blader, S. L. (2001). Identity and cooperative behavior in groups. Group processes \& intergroup relations, 4(3), 207-226.

Vaismoradi, M., Griffiths, P., Turunen, H. \& Jordan, S. (2016). Transformational leadership in nursing and medication safety education: A discussion paper. Journal of Nursing Management, 24(7), 970-980. https://doi.org/10.1111/jonm.12387.

Vieira, A., Alves, M., Monteiro, P. R. R. \& Garcia, F .C. (2013). Women in nursing teams: Organizational identification and experiences of pleasure and suffering. Revista Latino-Americana de Enfermagem, 21(5), 1127-1136. https://doi.org/10.1590/S0104-11692013000500016 


\section{Nurses' perceptions of patient safety culture}

Hemşirelerin hasta güvenliği kültürü algısı

Vifladt, A., Simonsen, B. O., Lydersen, S. \& Farup, P. G. (2016). Changes in patient safety culture after restructuring of intensive care units: Two cross-sectional studies. Intensive and Critical Care Nursing, 32, 58-65. https://doi.org/10.1016/j.iccn.2015.06.004.

Williams, J. C. (2014). Nurses'organizational commitment, job satisfaction, and perception of their managers'leadership style as predictors of perception of patient safety culture (Doctoral dissertation). Capella University, Minneapolis, ABD.

Yıldız, F. T. \& Yıldız, İ. (2020). Evaluation of knowledge and attitudes of nurses' towards medication application errors. The Turkish Journal of Science and Health, 1(1), 29-41. 